\title{
Nonenzymatic synthesis of anomerically pure, mannosyl- based molecular probes for scramblase identification studies
}

\author{
Giovanni Picca ${ }^{1}$, Markus Probst ${ }^{1}$, Simon M. Langenegger ${ }^{1}$, Oleg Khorev ${ }^{1}$, \\ Peter Bütikofer ${ }^{2}$, Anant K. Menon ${ }^{3}$ and Robert Häner ${ }^{* 1}$
}

\section{Full Research Paper}

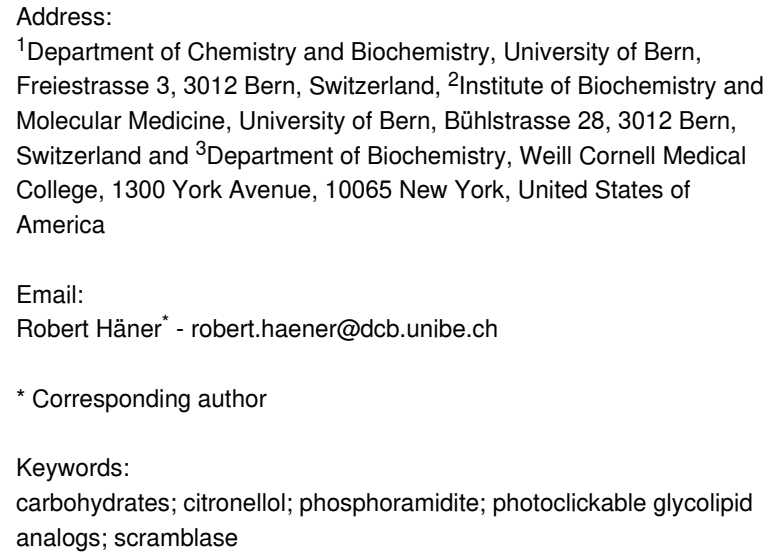

${ }^{1}$ Department of Chemistry and Biochemistry, University of Bern, Freiestrasse 3, 3012 Bern, Switzerland, ${ }^{2}$ Institute of Biochemistry and Molecular Medicine, University of Bern, Bühlstrasse 28, 3012 Bern, Switzerland and ${ }^{3}$ Department of Biochemistry, Weill Cornell Medical College, 1300 York Avenue, 10065 New York, United States of America

Email:

Robert Häner * - robert.haener@dcb.unibe.ch

* Corresponding author

\section{Keywords:}

carbohydrates; citronellol; phosphoramidite; photoclickable glycolipid

analogs; scramblase

Beilstein J. Org. Chem. 2020, 16, 1732-1739.

doi:10.3762/bjoc. 16.145

Received: 05 May 2020

Accepted: 09 July 2020

Published: 20 July 2020

Associate Editor: S. Flitsch

(C) 2020 Picca et al.; licensee Beilstein-Institut. License and terms: see end of document.

\begin{abstract}
The chemical synthesis of molecular probes to identify and study membrane proteins involved in the biological pathway of protein glycosylation is described. Two short-chain glycolipid analogs that mimic the naturally occurring substrate mannosyl phosphoryl dolichol exhibit either photoreactive and clickable properties or allow the use of a fluorescence readout. Both probes consist of a hydrophilic mannose headgroup that is linked to a citronellol derivative via a phosphodiester bridge. Moreover, a novel phosphoramidite chemistry-based method offers a straightforward approach for the non-enzymatic incorporation of the saccharide moiety in an anomerically pure form.
\end{abstract}

\section{Introduction}

Mannosyl phosphoryl dolichol (MPD), an important, multifunctional glycolipid, is used as a mannose donor for protein $\mathrm{N}$-glycosylation, O- and C-mannosylation, and glycosylphosphatidylinositol (GPI) anchoring in the luminal leaflet of the endoplasmic reticulum (ER) [1-8]. Interestingly, MPD is synthesized on the cytoplasmic face of the ER and must be translocated across the ER membrane to participate in luminal glyco- syltransfer reactions $[3,4]$. A specific membrane protein - MPD scramblase - is required to facilitate the transbilayer movement of MPD across the ER. Although the activity of MPD scramblase has been described in microsomal vesicles and reconstituted systems $[1,2,9]$, the molecular identity of this protein remains unknown. To circumvent the need for traditional purification strategies to identify the scramblase, we considered the 
use of photoreactive, clickable MPD mimics. As such, an attempt already showed great promise in a previous report by Rush et al. from 2015 [10]. Similarly, we envisioned that these analogs could be used to capture MPD-recognizing proteins, including the scramblase, from a crude mixture of ER membrane proteins $[11,12]$. The captured proteins would be subsequently identified by mass spectrometry, and their function in MPD scrambling validated by biochemical and genetic approaches.

A suitable molecular probe and mimic of MPD (Figure 1) can be subdivided into three essential components: a $\beta$-D-mannose (the $\alpha$-anomer also shows biological activity, but to a lesser extent) [13-15], a short-chain (citronellol) mimic of dolichol $[1,2,13]$, and a functional tag. The latter may either be a chemically reactive group (in MPC-1) or a fluorescent reporter group (in MPC-2). MPC-1 bears a benzophenone moiety for photocrosslinking to MPD-recognizing proteins. The presence of an additional propargyl group provides a way to further derivatize the probe with biotin azide via click-type chemistry [16] for the isolation of protein-lipid adducts using streptavidin resins [10]. To synthesize such molecular probes, previous studies relied on a chemoenzymatic approach to selectively incorporate the biologically relevant $\beta$-configured D-mannose headgroup as chemical approaches were deemed to be too challenging $[10,13]$. This method naturally has some limitations regarding the quantity of the obtained compound and the availability of the required mannosyltransferase. Here, we describe a purely chemical approach to synthesize a photoclickable MPD analog containing $\beta$-D-mannose (in MPC1). The chemical synthesis allows for a rapid upscaling of the reactions if necessary. In addition, having access to the individual building blocks (e.g., the phosphoramidites) will enable the creation of a series of molecular probes with different functional groups and varying linker lengths with relatively little effort.

The crucial step in the synthetic pathway consists of the conversion of the carbohydrate intermediates into stereodefined, anomeric phosphoramidite derivatives. The method is based on adapted procedures developed for DNA solid-phase synthesis [17]. Phosphoramidite chemistry allows the connection of two molecular entities via a phosphodiester linkage and was found to be perfectly suited for this purpose. Reports of using phos-

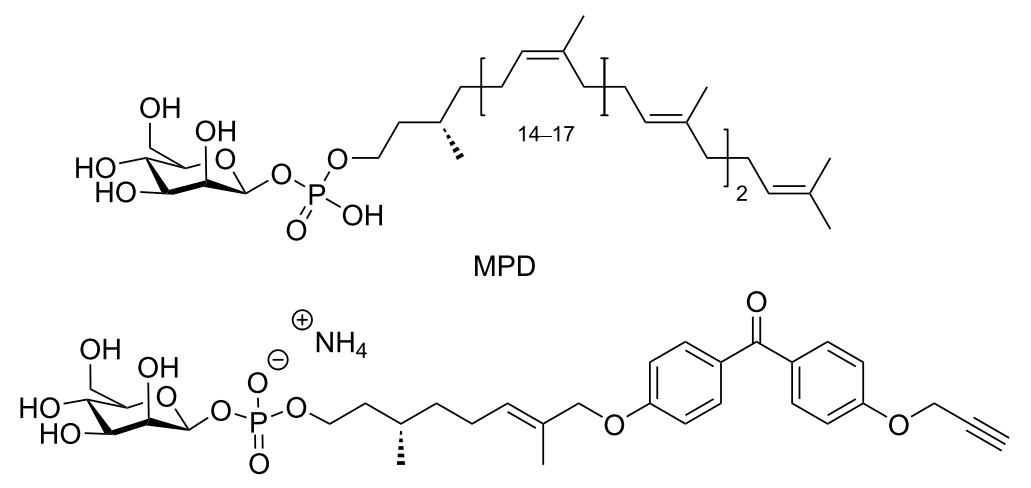<smiles>C/C(=C\CC[C@H](C)CCOP(=O)([O-])OC1C(O)C(O)C(O)(O)C1O)COCCCCCNc1ccc([N+](=O)[O-])c2nonc12</smiles><smiles>C#CCOc1ccc(C(=O)c2ccc(OC/C(C)=C/CC[C@H](C)CCOP(=O)([O-])OC3C4OC(O)(C(O)C(O)C4O)C3O)cc2)cc1</smiles>

Figure 1: Chemical structures of MPD and the three structural analogs MPC-1, MPC-2, and MPC-3. The molecular probes MPC-1 and MPC-3 are photoclickable derivatives, whereas the probe MPC-2 bears a fluorescent tag. 
phoramidite chemistry for the preparation of carbohydrates via the anomeric position are relatively rare [18-23]. Alternatively, the H-phosphonate approach has been used to convert carbohydrates into phosphate-linked derivatives at the anomeric center [24-29].

The phosphoramidite approach was also applied to the synthesis of a second molecular probe, MPC-2, an anomerically pure, $\beta$-linked D-mannosephosphate derivative, which serves as a fluorescent MPD analog for scramblase activity screening assays. Although similar experiments have been described with radioactively labeled substrates, the use of fluorescently labeled probes offers several advantages, including the continuous monitoring of the transport and a better time resolution. For reasons of comparison, the $\alpha$-configured D-mannose probe MPC-3 was synthesized in parallel. The characterization of the configuration at the anomeric position was done by HSQC NMR (see Supporting Information File 1). Since the target enzymes are unknown and can be expected to have stereospecific binding sites, the $\alpha$-configured D-mannose probe MPC-3 is also important as a reference for our biochemical assays (work in progress). The possibility to use both probes, MPC-1 and MPC-3, independently may help to reduce false-positive scramblase candidates.

\section{Results and Discussion}

The synthesis of the target compounds MPC-1 and MPC-2 started from commercially available $(S)$-citronellol (Cit), 4,4' dihydroxybenzophenone (BZP), D-mannose (Man), and 1,12dodecanediol (Dod, Figure 2).

Both the mannose and the phosphodiester bond were introduced via phosphoramidite chemistry to yield the final compounds, as shown in Figure 3. As opposed to the photoclickable probe MPC-1, the 4-chloro-7-nitro-1,2,3-benzoxadiazole (NBD)-labeled analog MPC-2 carries an additional dodecanyl linker between the citronellyl unit and the fluorophore. This is intended to increase the hydrophobic interactions between the probe and the lipid bilayer and also to increase the flexibility. More specifically, the probe should adopt a U-shaped structure in which the citronellyl-dodecanyl linker is located in the phos- pholipid membrane, and the mannose and the NBD are positioned in the surrounding aqueous medium. The close proximity of the NBD fluorophore to the membrane-water interface [30,31] allows for fluorescence-based scramblase assays wherein the NBD can be detected with dithionite. The latter reduces the nitro group of the NBD rapidly into an amino group, rendering the fluorophore nonfluorescent [32-34]. While there are no noteworthy difficulties in the synthesis of the molecular probe MPC-1 to report, the same cannot be said for MPC-2. There, the NBD tag was only partially stable to the conditions used to remove the protecting groups in the final step $\left(\mathrm{NH}_{3}\right.$ in $\mathrm{MeOH}$, Figure 3). Under such alkaline conditions, a considerable amount of degradation of NBD was observed, making an additional purification step necessary to obtain pure MPC-2 (see Supporting Information File 1).

As shown in Figure 3, the acetylated mannose phosphoramidite 及-4Ac-Man-CEP was coupled to the free hydroxy group of the citronellol derivatives containing the functional tags (Cit-BZPyne or Cit-Dod-NBD). The reactions were performed in dichloromethane (DCM), and ETT served as the activator. The subsequent oxidation of the unstable phosphite triester to the more stable phosphotriester was performed with $t$-BuOOH. The resulting intermediates were then treated overnight with a solution of ammonia in methanol to remove the protecting groups. An overall yield of about $45 \%$ was achieved when no further purification was carried out (for details see Supporting Information File 1).

The major goal of this work was the synthesis of molecular probes with a configurationally defined mannosyl headgroup, i.e., a pure $\beta$-anomer. In order to verify the preferred configuration at the anomeric position and to prove the working principle of our synthetic strategy, we used 2D NMR experiments. Coupled HSQC measurements revealed the ${ }^{1} J_{\mathrm{CH}}$ coupling constants of our compounds and thereby the absolute configuration at the anomeric center of the carbohydrate [40-42]. For MPC-1 and MPC-2, ${ }^{1} J_{\mathrm{CH}}$ values $158 \mathrm{~Hz}$ and $161 \mathrm{~Hz}$, respectively, were obtained (for comparison, for MPC-3 containing almost exclusively the $\alpha$-anomer, a value of about $171 \mathrm{~Hz}$ was determined, see Supporting Information File 1).<smiles>CC(C)=CCC[C@H](C)CCO</smiles>

Cit<smiles>O=C(c1ccc(O)cc1)c1ccc(O)cc1</smiles>

BZP

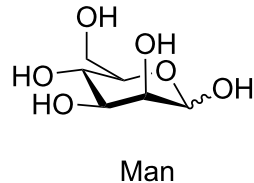<smiles>CC(C)(CO)CCCO</smiles>

Dod 


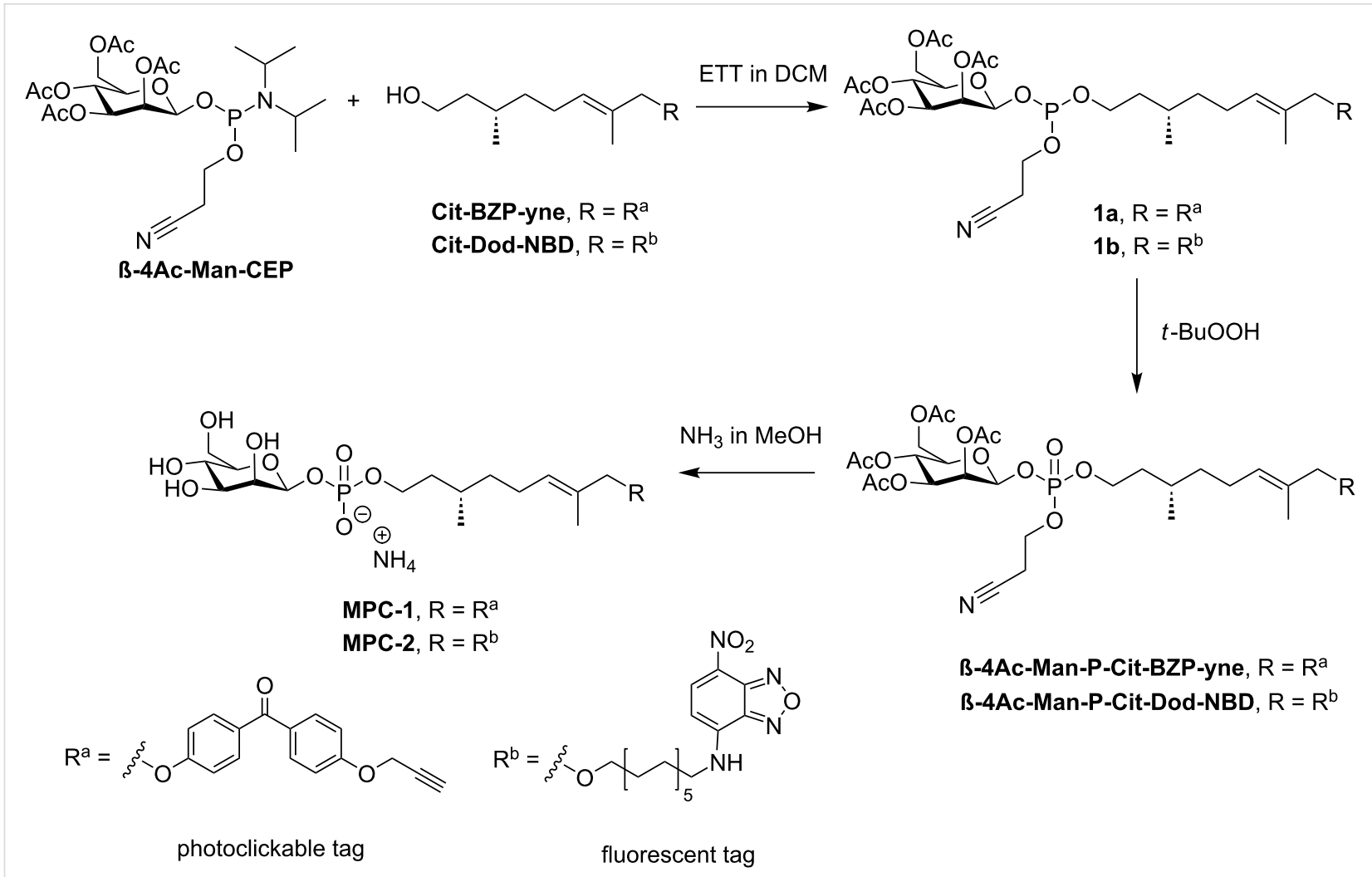

Figure 3: The synthetic route leading to compounds MPC-1 and MPC-2. Compound $\boldsymbol{\beta}-\mathbf{4 A C}-\mathbf{M a n}-\mathbf{C E P}$ was prepared in 4 steps from D-mannose (see Supporting Information File 1) $[35,36]$. Compound Cit-BZP-yne was prepared via a Mitsunobu reaction of tetrahydropyranyl (THP)-protected citronellol and a hydroxylated benzophenone derivative [10,37,38]. Compound Cit-Dod-NBD was obtained in 10 steps, starting from citronellol and tert-butyldimethylsilyl (TBDMS)-protected dodecanediol [39]. The reaction of either of the alcohols with the sugar phosphoramidite using ETT led to phosphite intermediates $\mathbf{1 a}$ and $\mathbf{1 b}$, respectively. The intermediates were then oxidized with $t-\mathrm{BuOOH}$, and finally, the protecting groups were removed under basic conditions to give either MPC-1 or MPC-2 as ammonium salts. ETT = 5-(ethylthio)- $1 H$-tetrazole.

As highlighted above, the most important step in the chemical synthesis of the target compounds MPC-1 and MPC-2 was the preparation of the phosphoramidite $\beta-4 A c-M a n-C E P$ (Figure 4). Two points are of particular importance for the synthesis of this compound. Firstly, we needed access to an anomerically pure starting material, i.e., 2,3,4,6-tetra- $O$-acetyl-
$\beta$-D-mannopyranose. This was achieved by following literature procedures $[35,36]$, which provided the pure $\beta$-anomer as a crystalline solid. Secondly, suitable conditions had to be identified for the subsequent phosphitylation conditions under which no mutarotation of the carbohydrate occurs. Cooling of the reaction mixture and performing the reaction at a temperature below

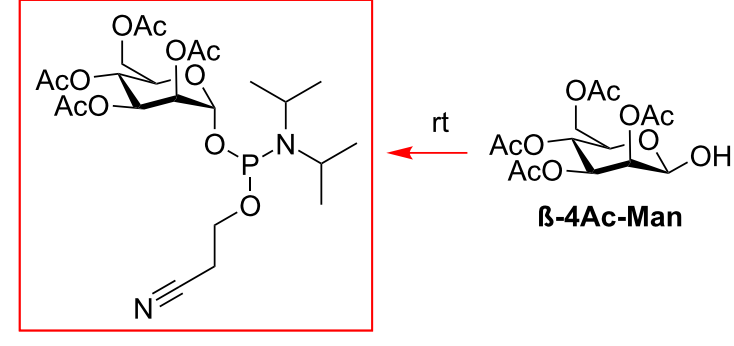

$\alpha-4 A c-M a n-C E P$

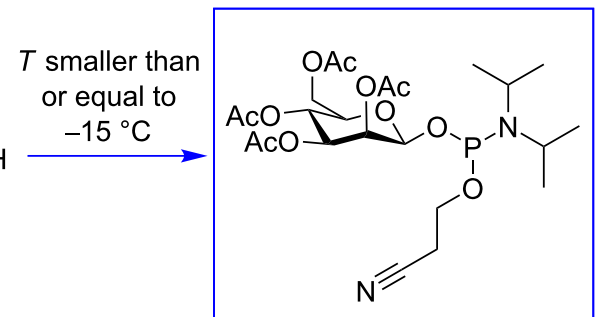

ß-4AC-Man-CEP

Figure 4: Preparation of mannosyl phosphoramidites. Starting from 2,3,4,6-tetra-O-acetyl- $\beta$-D-mannopyranose ( $\boldsymbol{\beta}$-4Ac-Man), the phosphitylation using 2 -cyanoethyl $N, N$-diisopropylchlorophosphoramidite (CEP-CI) and DIPEA provides $\beta$-4Ac-Man-CEP when the reaction is performed at a temperature below $-15^{\circ} \mathrm{C}(15-30 \mathrm{~min}$ reaction time). When the reaction is carried out at room temperature, epimerization leads to $2,3,4,6$-tetra-O-acetyl- $\alpha$-Dmannopyranose (not shown), which is subsequently converted to $\alpha-4$ Ac-Man-CEP. 
$-15{ }^{\circ} \mathrm{C}$ yielded the compound $\boldsymbol{\beta}-\mathbf{4 A c}-\mathbf{M a n}-\mathbf{C E P}$, with no traces of the $\alpha$-anomer. The configuration was then retained throughout the rest of the synthesis, as indicated by the NMR data of MPC-1 and MPC-2 (Supporting Information File 1).

\section{Conclusion}

We report herein the successful chemical synthesis of molecular probes for identifying and studying MPD scramblase, as well as proteins that use MPD as a mannosyl donor. Two types of probes were synthesized; both are short-chain glycolipid analogs. One, MPC-1, contains a photoreactive clickable tag to capture scramblase candidates (identification by mass spectrometry), and the other probe, MPC-2, consists of a fluorescent label to test candidates for scramblase activity in reconstitutionbased assays. The molecular probes were prepared via phosphoramidite chemistry, which allowed the incorporation of the carbohydrate headgroup and simultaneously introduced the linking phosphate group. Furthermore, we demonstrate a novel, reliable, and efficient way to synthesize the carbohydrate phosphoramidite with a defined configuration at the anomeric position, a strategy that gives access to future molecular probes containing pure $\beta$-D-mannose, which was previously only accessible through a chemoenzymatic approach.

\section{Experimental Synthesis}

Detailed descriptions of the synthesis and the analytical data (NMR and MS spectra) are provided in Supporting Information File 1.

\section{Cit-BZP-yne}

THP-Cit-BZP-yne (279 mg, $0.57 \mathrm{mmol}, 1$ equiv) was dissolved in anhydrous ethanol $(8 \mathrm{~mL})$, and pyridinium $p$-toluenesulfonate (PPTS, $286 \mathrm{mg}, 1.14 \mathrm{mmol}, 2$ equiv) was added. The solution was stirred at $60{ }^{\circ} \mathrm{C}$ for $2.5 \mathrm{~h}$. The reaction mixture (at rt) was poured into a separating funnel containing diethyl ether $(40 \mathrm{~mL})$ and brine $(16 \mathrm{~mL})$. The organic layer was dried over $\mathrm{MgSO}_{4}$, and the volatile components were removed under reduced pressure. The yellowish residue (crude product) was purified by flash chromatography over silica gel, with a mixture of $n$-hexane/ethyl acetate $3: 2, \mathrm{v} / \mathrm{v}$ as eluent. The fractions containing the product $\left(R_{\mathrm{f}}=0.22\right.$ in $n$-hexane/ethyl acetate $3: 2$, $\mathrm{v} / \mathrm{v})$ were combined, and the solvents were removed under reduced pressure on a rotary evaporator to give Cit-BZP-yne (154 mg, $0.38 \mathrm{mmol}, 67 \%$ ) as white solid. ${ }^{1} \mathrm{H}$ NMR (300 MHz, $\left.\mathrm{CDCl}_{3}, \delta\right): 7.85-7.72(\mathrm{~m}, 4 \mathrm{H}), 7.09-6.99(\mathrm{~m}, 2 \mathrm{H}), 7.02-6.91(\mathrm{~m}$, 2H), 5.61-5.49 (m, 1H), 4.77 (d, $J=2.4 \mathrm{~Hz}, 2 \mathrm{H}), 4.47(\mathrm{~s}, 2 \mathrm{H})$ $3.69(\mathrm{~m}, 2 \mathrm{H}), 2.56(\mathrm{t}, J=2.4 \mathrm{~Hz}, 1 \mathrm{H}), 2.21-1.98(\mathrm{~m}, 2 \mathrm{H}), 1.74$ (s, 3H), 1.70-1.50 (m, 1H), 1.50-1.15 (m, 4H), $0.92(\mathrm{~d}, J=$ $6.4 \mathrm{~Hz}, 3 \mathrm{H}) ;{ }^{13} \mathrm{C} \mathrm{NMR}\left(75 \mathrm{MHz}, \mathrm{CDCl}_{3}, \delta\right) 194.48,162.39$, 160.64, 132.22, 132.14, 131.64, 130.51, 130.29, 129.82, 114.37,
114.36, 77.92, 76.10, 74.21, 61.12, 55.89, 39.83, 36.63, 29.18, $25.20,19.46,13.85$.

\section{及-4AC-Man-CEP}

及-4Ac-Man (100 mg, $0.29 \mathrm{mmol}, 1$ equiv) was dissolved in anhydrous DCM $(4 \mathrm{~mL})$ at $-60{ }^{\circ} \mathrm{C}$. Then, DIPEA $(75 \mu \mathrm{L}$, $0.43 \mathrm{mmol}, 1.5$ equiv) was added, followed by the addition of CEP-Cl ( $77 \mu \mathrm{L}, 0.35 \mathrm{mmol}, 1.2$ equiv). The mixture was stirred for $30 \mathrm{~min}$ at $-50{ }^{\circ} \mathrm{C}$ under argon. The crude product was then directly purified by flash chromatography using ethyl acetate $/ n$ hexane $1: 1, \mathrm{v} / \mathrm{v}+2 \%$ triethylamine. The fractions containing the product $\left(R_{\mathrm{f}}=0.40\right)$ were combined, and the solvents were removed under reduced pressure on a rotary evaporator. The product was extensively dried to give $\beta-4 A c-M a n-C E P$ (145 mg, $0.26 \mathrm{mmol}, 92 \%$ ) as colorless foam. ${ }^{1} \mathrm{H} \mathrm{NMR}$ $\left(300 \mathrm{MHz}, \mathrm{CDCl}_{3}, \delta\right) 5.37(\mathrm{dd}, J=25.2,3.3 \mathrm{~Hz}, 1 \mathrm{H}), 5.19(\mathrm{t}$, $J=9.9 \mathrm{~Hz}, 1 \mathrm{H}), 5.12-4.95(\mathrm{~m}, 2 \mathrm{H}), 4.24-4.09(\mathrm{~m}, 2 \mathrm{H})$, $3.91-3.48(\mathrm{~m}, 5 \mathrm{H}), 2.66-2.53(\mathrm{~m}, 2 \mathrm{H}), 2.14(\mathrm{~s}, 3 \mathrm{H}), 2.05-2.00$ $(\mathrm{m}, 8 \mathrm{H}), 1.95(\mathrm{~d}, J=1.6 \mathrm{~Hz}, 3 \mathrm{H}), 1.12(\mathrm{dd}, J=10.8 ; 6.9 \mathrm{~Hz}$, $12 \mathrm{H}$ ); ${ }^{13} \mathrm{C} \mathrm{NMR}\left(75 \mathrm{MHz}, \mathrm{CDCl}_{3}, \delta\right): 170.58,170.55,170.31$, 170.10, 169.98, 169.94, 169.67, 169.63, 117.63, 93.69, 93.57, 93.36, 72.72, 72.66, 70.98, 69.78, 69.69, 65.99, 65.90, 62.67, $62.43,59.20,58.96,58.78,58.53,44.07,43.90,43.77,43.59$, $24.61,24.52,24.43,24.34,24.04,23.94,20.80,20.77,20.68$, 20.56, 20.34, 20.25, 20.14, 20.06; ${ }^{31} \mathrm{P}$ NMR (121 MHz, $\mathrm{CDCl}_{3}$, ठ) $153.31,150.00$.

\section{MPC-1}

ETT (72 $\mathrm{mg}, 0.55 \mathrm{mmol}, 1.5$ equiv) was dissolved in anhydrous DCM (2 mL), $\boldsymbol{\beta}$-4Ac-Man-CEP (223 mg, $0.41 \mathrm{mmol}$, 1.1 equiv) was added, and the resultant solution was added to a solution of Cit-BZP-yne (150 mg, $0.37 \mathrm{mmol}, 1$ equiv) dissolved in anhydrous DCM $(2 \mathrm{~mL})$. The reaction mixture was stirred for $30 \mathrm{~min}$ at $\mathrm{rt}$ under argon. Afterwards, a $t-\mathrm{BuOOH}$ solution $(201 \mu \mathrm{L}, 1.11 \mathrm{mmol}, 3$ equiv, $\approx 5.5 \mathrm{M}$ in decane) was added, and the mixture was stirred for an additional $15 \mathrm{~min}$. The reaction mixture was diluted with toluene $(60 \mathrm{~mL})$ and then washed with a saturated sodium hydrogen carbonate solution $(30 \mathrm{~mL})$ and brine $(30 \mathrm{~mL})$. The organic layer was dried over $\mathrm{MgSO}_{4}$, and the volatile components were removed under reduced pressure. The resulting residue was dissolved in methanol and purified by PLC (using ethyl acetate/ $n$-hexane 2:1, v/v as a mobile phase). The broad band, located at the very bottom of the plate $\left(R_{\mathrm{f}} \approx 0.10\right.$ using ethyl acetate $/ n$-hexane $\left.1: 1, \mathrm{v} / \mathrm{v}\right)$ was removed, and the intermediate $\beta$-4Ac-Man-P-Cit-BZPyne was extracted with methanol $(150 \mathrm{~mL})$. The solvent was removed under reduced pressure on a rotary evaporator. Then, an ammonia solution ( $3 \mathrm{~mL}, 2.0 \mathrm{M}$ in methanol) was added, and the reaction mixture was stirred overnight at $\mathrm{rt}$. The resulting solution was first diluted with methanol $(2 \mathrm{~mL})$, and the volatile components were removed under reduced pressure. Then, 
distilled water $(2 \mathrm{~mL})$ was added, and the material was lyophilized overnight to afford MPC-1 $(110 \mathrm{mg}, 0.17 \mathrm{mmol}$, $46 \%)$ as yellowish solid. ${ }^{1} \mathrm{H}$ NMR $\left(400 \mathrm{MHz}\right.$, DMSO- $\left.d_{6}, \delta\right)$ 7.75-7.66 (m, 4H), 7.17-7.04 (m, 4H), $5.58(\mathrm{t}, J=6.7 \mathrm{~Hz}, 1 \mathrm{H})$, $4.92(\mathrm{~d}, J=2.4 \mathrm{~Hz}, 2 \mathrm{H}), 4.87(\mathrm{~d}, J=8.5 \mathrm{~Hz}, 1 \mathrm{H}), 4.51(\mathrm{~s}, 2 \mathrm{H})$, $3.77-3.61(\mathrm{~m}, 5 \mathrm{H}), 3.62-3.32(\mathrm{~m}, 2 \mathrm{H}), 3.33-3.25(\mathrm{~m}, 2 \mathrm{H}), 2.05$ $(\mathrm{m}, 2 \mathrm{H}), 1.69(\mathrm{~s}, 3 \mathrm{H}), 1.62-1.48(\mathrm{~m}, 2 \mathrm{H}), 1.42-1.26(\mathrm{~m}, 2 \mathrm{H})$, $1.26-1.13(\mathrm{~m}, 1 \mathrm{H}), 0.87(\mathrm{~d}, J=6.2 \mathrm{~Hz}, 3 \mathrm{H}) ;{ }^{13} \mathrm{C} \mathrm{NMR}$ (101 MHz, DMSO- $\left.d_{6}, \delta\right) 193.64,162.46,160.86,132.29$, 132.13, 131.24, 130.63, 130.30, 129.66, 115.07, 115.02, 96.07, $96.04,79.25,79.20,74.05,73.98,71.53,71.48,67.39,63.02$, $62.97,61.82,56.20,37.85,37.78,36.76,36.36,29.33,25.14$, $19.69,14.17 ;{ }^{31} \mathrm{P}$ NMR (121 MHz, DMSO- $\left.d_{6}, \delta\right) 25.54,4.74$, -2.89 .

\section{Cit-Dod-NBD}

DMT-Cit-Dod-NBD (787 mg, $0.96 \mathrm{mmol}$ ) was dissolved in a trichloroacetic acid solution ( $3 \%$ in DCM/MeOH 1:1, v/v) at rt. The reaction mixture was stirred for $2 \mathrm{~h}$. The mixture was diluted with DCM, washed with brine, and the organic phase was dried with $\mathrm{Na}_{2} \mathrm{SO}_{4}$. The purification by column chromatography on silica gel (hexane/EtOAc 6:4, v/v) gave Cit-Dod-NBD (455 mg, 92\%) as red oil $\left(R_{\mathrm{f}}=0.5\right.$ in hexane/EtOAc 1:1, v/v). ${ }^{1} \mathrm{H}$ NMR (DMSO-d $\left.d_{6}, 300 \mathrm{MHz}, \delta\right) 9.55(\mathrm{~s}, 1 \mathrm{H}), 8.50(\mathrm{~d}, J=$ $8.8 \mathrm{~Hz}, 1 \mathrm{H}), 6.49-6.31(\mathrm{~m}, 1 \mathrm{H}), 5.33(\mathrm{t}, J=7.2 \mathrm{~Hz}, 1 \mathrm{H}), 4.28$ $(\mathrm{t}, J=5.1 \mathrm{~Hz}, 1 \mathrm{H}), 3.73(\mathrm{~s}, 2 \mathrm{H}), 3.59-3.36(\mathrm{~m}, 4 \mathrm{H}), 3.26(\mathrm{t}, J=$ $6.4 \mathrm{~Hz}, 2 \mathrm{H}), 1.74-1.61(\mathrm{~m}, 2 \mathrm{H}), 1.55$ (s, 3H), 1.52-1.40 (m, $4 \mathrm{H}), 1.24(\mathrm{~s}, 19 \mathrm{H}), 0.84(\mathrm{~d}, J=6.5 \mathrm{~Hz}, 3 \mathrm{H}) ;{ }^{13} \mathrm{C}$ NMR (DMSO$\left.d_{6}, 75 \mathrm{MHz}, \delta\right) 132.41,127.51,99.47,79.67,76.21,69.19$, $63.78,59.24,37.01,33.97,30.68,29.63,29.47,29.42,29.18$, $28.81,28.06,26.85,26.19,25.00,24.92,19.86,19.09,14.06$, 13.99 .

\section{MPC-2}

ETT (38 mg, $0.29 \mathrm{mmol}, 1.5$ equiv) was dissolved in anhydrous DCM (2 mL), $\boldsymbol{\beta}$-4Ac-Man-CEP (116 mg, $0.21 \mathrm{mmol}$, 1.1 equiv) was added, and the resultant solution was added to Cit-Dod-NBD (100 mg, 0.19 mmol, 1 equiv) dissolved in anhydrous DCM $(1 \mathrm{~mL})$. The reaction mixture was stirred for $30 \mathrm{~min}$ at $\mathrm{rt}$ under argon. Afterwards, a $t$ - $\mathrm{BuOOH}$ solution $(110 \mu \mathrm{L}, 0.61 \mathrm{mmol}, 3$ equiv, $\approx 5.5 \mathrm{M}$ in decane) was added, and the mixture was stirred for an additional $15 \mathrm{~min}$. The reaction mixture was poured into a separating funnel containing DCM $(15 \mathrm{~mL})$ and a saturated sodium hydrogen carbonate solution $(15 \mathrm{~mL})$. The organic layer was further washed with brine $(15 \mathrm{~mL})$ and then dried with $\mathrm{MgSO}_{4}$. The volatile components were removed under reduced pressure, the brownish residue was redissolved in acetonitrile $(1.5 \mathrm{~mL})$ and purified by PLC (using a mixture of ethyl acetate/n-hexane $1: 1, \mathrm{v} / \mathrm{v}$ as the mobile phase). The broad band located at the very bottom of the plate $\left(R_{\mathrm{f}} \approx 0.10\right.$ using ethyl acetate $/ n$-hexane $\left.1: 1, \mathrm{v} / \mathrm{v}\right)$ was removed, and the intermediate $\beta-4 A c-M a n-P-C i t-D o d-N B D$ was extracted with acetonitrile $(180 \mathrm{~mL})$. The solvent was removed under reduced pressure on a rotary evaporator. The material was then treated overnight with an ammonia solution $(2 \mathrm{~mL}, 2.0 \mathrm{M}$ in methanol). Afterwards, the reaction mixture was diluted with methanol $(2 \mathrm{~mL})$, the volatile components were removed under reduced pressure, and the orange-brownish residue (redissolved in $1.5 \mathrm{~mL}$ methanol) was purified by PLC (using chloroform/ methanol/water 60:25:4, v/v/v as the mobile phase). The broad band, centered at around an $R_{\mathrm{f}}$ of about 0.22 , was removed, and the product was extracted with methanol $(170 \mathrm{~mL})$. The solvent was removed under reduced pressure on a rotary evaporator, the residue dissolved in distilled water $(1.3 \mathrm{~mL})$, and the material was lyophilized overnight to give MPC-2 (65 mg, $0.09 \mathrm{mmol}$, 45\%). ${ }^{1} \mathrm{H}$ NMR (300 MHz, $\left.\mathrm{D}_{2} \mathrm{O}, \delta\right) 8.27$ (s, 1H), 6.17 (s, 1H), 5.35 (s, 1H), $5.13(\mathrm{~d}, J=8.4 \mathrm{~Hz}, 1 \mathrm{H}), 4.14-3.53(\mathrm{~m}, 10 \mathrm{H})$, 3.50-3.19 (m, 4H), 2.05-1.99 (m, 2H), 1.78-1.42 (m, 9H), $1.33-1.08(\mathrm{~m}, 21 \mathrm{H}), 0.91(\mathrm{~d}, J=6.0 \mathrm{~Hz}, 3 \mathrm{H}) ;{ }^{13} \mathrm{C} \mathrm{NMR}$ $\left(101 \mathrm{MHz}, \mathrm{D}_{2} \mathrm{O}, \delta\right) 131.98,131.89,131.83,128.40,128.33$, $95.42,95.38,76.90,76.65,72.73,71.17,71.12,69.33,69.32$, $66.19,64.79,61.20,60.82,37.11,29.76,29.61,29.52,29.39$, 29.23, 26.26, 25.09, 18.99, 13.57; ${ }^{31}$ P NMR (121 MHz, $\left.\mathrm{D}_{2} \mathrm{O}, \delta\right)$ $7.22,-1.64$.

\section{MPC-3}

Compound $\boldsymbol{\alpha - 4 A c - M a n - C E P}$ was prepared according to published procedures [22] (for more information see Supporting Information File 1).

- -4 Ac-Man-CEP (252 mg, $0.46 \mathrm{mmol}, 1.1$ equiv) and ETT (82 mg, $0.63 \mathrm{mmol}, 1.5$ equiv) were dissolved in anhydrous DCM (1 mL) and Cit-BZP-yne (170 mg, $0.42 \mathrm{mmol}, 1$ equiv, dissolved in $1.5 \mathrm{~mL}$ anhydrous DCM) was added. The reaction mixture was stirred for $30 \mathrm{~min}$ at $\mathrm{rt}$ under argon. Afterwards, a $t$-BuOOH solution $(182 \mu \mathrm{L}, 1.31 \mathrm{mmol}, 3$ equiv, $70 \mathrm{wt} \%$ in $\mathrm{H}_{2} \mathrm{O}$ ) was added, and the solution was stirred for an additional $15 \mathrm{~min}$. The reaction mixture was diluted with toluene $(15 \mathrm{~mL})$ and poured into a separating funnel containing a saturated sodium hydrogen carbonate solution $(10 \mathrm{~mL})$. The organic phase was washed with brine, dried with $\mathrm{MgSO}_{4}$, and the volatile components were removed under reduced pressure. The resulting material was then dissolved in DCM and purified by flash chromatography on silica gel using ethyl acetate/ $n$-hexane $7: 3$, $\mathrm{v} / \mathrm{v}$ as eluent. The fractions containing the intermediate $\boldsymbol{\alpha}-\mathbf{4 A c}-$ Man-P-Cit-BZP-yne $\left(R_{\mathrm{f}}=0.33\right.$ using the same solvent system as for the column) were combined, and the solvents were removed under reduced pressure on a rotary evaporator. To the white residue, an ammonia solution (4 $\mathrm{mL}, 2.0 \mathrm{M}$ in methanol) was added, and the reaction mixture was stirred overnight at rt. Afterwards, the volatile components were removed under reduced pressure, the residue was dissolved in methanol $(2 \mathrm{~mL})$, 
and the material was purified by PLC (using chloroform/methanol/water $60: 25: 4, \mathrm{v} / \mathrm{v} / \mathrm{v}$ as the mobile phase). The broad band, centered at around $R_{\mathrm{f}} \approx 0.19$, was removed, and the product was extracted with methanol $(100 \mathrm{~mL})$. The solvent was removed under reduced pressure on a rotary evaporator to give MPC-3 (65 mg, $0.10 \mathrm{mmol}, 24 \%$ ) as white solid. ${ }^{1} \mathrm{H}$ NMR (400 MHz, DMSO- $\left.d_{6}, \delta\right)$ 7.75-7.64 (m, 4H), 7.16-7.04 (m, 4H), $5.58(\mathrm{t}$, $J=7.2 \mathrm{~Hz}, 1 \mathrm{H}), 5.17(\mathrm{dd}, J=7.8,1.9 \mathrm{~Hz}, 1 \mathrm{H}), 4.91(\mathrm{~d}, J=$ $2.4 \mathrm{~Hz}, 2 \mathrm{H}), 4.88-4.87(\mathrm{~m}, 3 \mathrm{H}), 4.76-4.71(\mathrm{~m}, 2 \mathrm{H}), 4.50$ (s, $2 \mathrm{H}), 3.77-3.63(\mathrm{~m}, 2 \mathrm{H}), 3.63-3.51(\mathrm{~m}, 4 \mathrm{H}), 3.42-3.23(\mathrm{~m}, 2 \mathrm{H})$, $2.04(\mathrm{~m}, 2 \mathrm{H}), 1.69(\mathrm{~s}, 3 \mathrm{H}), 1.60-1.45(\mathrm{~m}, 2 \mathrm{H}), 1.41-1.24(\mathrm{~m}$, $2 \mathrm{H}), 1.24-1.10(\mathrm{~m}, 1 \mathrm{H}), 0.85(\mathrm{~d}, J=6.4 \mathrm{~Hz}, 3 \mathrm{H}) ;{ }^{13} \mathrm{C} \mathrm{NMR}$ (101 MHz, DMSO- $\left.d_{6}, \delta\right) 193.74,162.47,160.84,132.31$, 132.15, 131.22, 130.61, 130.26, 129.71, 115.07, 115.03, 96.05, $95.99,79.24,79.14,74.51,74.06,71.46,71.38,70.92,67.64$, $62.81,62.76,61.80,56.17,37.90,37.83,36.75,29.30,25.11$, 19.68, 14.16; ${ }^{31} \mathrm{P}$ NMR (121 MHz, DMSO- $\left.d_{6}, \delta\right)-2.86$.

\section{Supporting Information}

\section{Supporting Information File 1}

Complete descriptions of the syntheses, including the precursors THP-Cit-BZP-yne and DMT-Cit-Dod-NBD, additional information about $\boldsymbol{\alpha}-\mathbf{4 A c}-\mathrm{Man}$, and the analytical data: NMR and HRMS spectra. [https://www.beilstein-journals.org/bjoc/content/ supplementary/1860-5397-16-145-S1.pdf]

\section{Funding}

Financial support by the Swiss National Science Foundation (SNSF) is gratefully acknowledged: This research was funded by the Sinergia Project: Molecular identification of lipid transporters for protein glycosylation, Grant CRSII5_170923.

\section{ORCID ${ }^{\circledR}$ iDs}

Oleg Khorev - https://orcid.org/0000-0001-6128-3831 Peter Bütikofer - https://orcid.org/0000-0001-9360-1013 Anant K. Menon - https://orcid.org/0000-0001-6924-2698 Robert Häner - https://orcid.org/0000-0001-5014-4318

\section{References}

1. Rush, J. S.; Waechter, C. J. J. Cell Biol. 1995, 130, 529-536. doi:10.1083/jcb.130.3.529

2. Sanyal, S.; Menon, A. K. Proc. Natl. Acad. Sci. U. S. A. 2010, 107, 11289-11294. doi:10.1073/pnas.1002408107

3. Schenk, B.; Fernandez, F.; Waechter, C. J. Glycobiology 2001, 11, 61R-70R. doi:10.1093/glycob/11.5.61r

4. Sanyal, S.; Menon, A. K. ACS Chem. Biol. 2009, 4, 895-909. doi:10.1021/cb900163d
5. Orlean, P.; Menon, A. K. J. Lipid Res. 2007, 48, 993-1011. doi:10.1194/jlr.r700002-jlr200

6. Anand, M.; Rush, J. S.; Ray, S.; Doucey, M.-A.; Weik, J.; Ware, F. E.; Hofsteenge, J.; Waechter, C. J.; Lehrman, M. A. Mol. Biol. Cell 2001, 12, 487-501. doi:10.1091/mbc.12.2.487

7. Neubert, P.; Strahl, S. Curr. Opin. Cell Biol. 2016, 41, 100-108. doi:10.1016/j.ceb.2016.04.010

8. Hofsteenge, J.; Müller, D. R.; de Beer, T.; Löffler, A.; Richter, W. J.; Vliegenthart, J. F. G. Biochemistry 1994, 33, 13524-13530. doi:10.1021/bi00250a003

9. Rush, J. S.; Waechter, C. J. Biochemistry 2004, 43, 7643-7652. doi:10.1021/bi036083o

10. Rush, J. S.; Subramanian, T.; Subramanian, K. L.; Onono, F. O.; Waechter, C. J.; Spielmann, P. H. Curr. Chem. Biol. 2015, 9, 123-141. doi:10.2174/2212796810666160216221610

11. Murale, D. P.; Hong, S. C.; Haque, M. M.; Lee, J.-S. Proteome Sci. 2016, 15, 14. doi:10.1186/s12953-017-0123-3

12. Smith, E.; Collins, I. Future Med. Chem. 2015, 7, 159-183. doi:10.4155/fmc.14.152

13. Rush, J. S.; Waechter, C. J. Partial Purification of Mannosylphosphorylundecaprenol Synthase From Micrococcus Luteus. In Glycobiology Protocols; Brockhausen, I., Ed.; Methods in Molecular Biology, Vol. 347; Humana Press: Clifton, NJ, U.S.A., 2006; pp 13-30. doi:10.1385/1-59745-167-3:13

14. Rush, J. S.; Shelling, J. G.; Zingg, N. S.; Ray, P. H.; Waechter, C. J. J. Biol. Chem. 1993, 268, 13110-13117.

15. Dotson, S. B.; Rush, J. S.; Ricketts, A. D.; Waechter, C. J. Arch. Biochem. Biophys. 1995, 316, 773-779. doi:10.1006/abbi.1995.1103

16. Kolb, H. C.; Finn, M. G.; Sharpless, K. B. Angew. Chem., Int. Ed. 2001, 40, 2004-2021.

doi:10.1002/1521-3773(20010601)40:11<2004::aid-anie2004>3.0.co;25

17. Beaucage, S. L.; Caruthers, M. H. Tetrahedron Lett. 1981, 22, 1859-1862. doi:10.1016/s0040-4039(01)90461-7

18. Ogawa, T.; Seta, A. Carbohydr. Res. 1982, 110, c1-c4. doi:10.1016/0008-6215(82)85040-4

19. Majumdar, D.; Elsayed, G. A.; Buskas, T.; Boons, G.-J. J. Org. Chem. 2005, 70, 1691-1697. doi:10.1021/jo048443z

20. Rutschow, S.; Thiem, J.; Kranz, C.; Marquardt, T. Bioorg. Med. Chem. 2002, 10, 4043-4049. doi:10.1016/s0968-0896(02)00269-9

21. Hara, R. I.; Kobayashi, S.; Noro, M.; Sato, K.; Wada, T. Tetrahedron 2017, 73, 4560-4565. doi:10.1016/j.tet.2017.06.015

22. Elsayed, G. A.; Boons, G.-J. Synlett 2003, 1373-1375. doi:10.1055/s-2003-40344

23. Delbianco, M.; Bharate, P.; Varela-Aramburu, S.; Seeberger, P. H. Chem. Rev. 2016, 116, 1693-1752. doi:10.1021/acs.chemrev.5b00516

24. Nikolaev, A. V.; Ivanova, I. A.; Shibaev, V. N. Carbohydr. Res. 1993, 242, 91-107. doi:10.1016/0008-6215(93)80024-9

25. Hermans, J. P. G.; de Vroom, E.; Elie, C. J. J.; van der Marel, G. A.; van Boom, J. H. Recl. Trav. Chim. Pays-Bas 1986, 105, 510-511. doi:10.1002/recl.19861051108

26. Naundorf, A.; Natsch, S.; Klaffke, W. Tetrahedron Lett. 2000, 41, 189-192. doi:10.1016/s0040-4039(99)02020-1

27. Nikolaev, A. V.; Ivanova, I. A.; Shibaev, V. N.; Kochetkov, N. K. Carbohydr. Res. 1990, 204, 65-78. doi:10.1016/0008-6215(90)84021-I

28. Sharipova, R. R.; Garifullin, B. F.; Sapunova, A. S.; Voloshina, A. D.; Kravchenko, M. A.; Kataev, V. E. Russ. J. Bioorg. Chem. 2019, 45, 155-164. doi:10.1134/s1068162019020110 
29. Garegg, P. J.; Hansson, J.; Helland, A.-C.; Oscarson, S. Tetrahedron Lett. 1999, 40, 3049-3052. doi:10.1016/s0040-4039(99)00362-7

30. Balcom, B. J.; Petersen, N. O. Biophys. J. 1993, 65, 630-637. doi:10.1016/s0006-3495(93)81106-8

31. Chattopadhyay, A. Chem. Phys. Lipids 1990, 53, 1-15. doi:10.1016/0009-3084(90)90128-e

32. Kern, N. R.; Lee, H. S.; Wu, E. L.; Park, S.; Vanommeslaeghe, K.; MacKerell, A. D., Jr.; Klauda, J. B.; Jo, S.; Im, W. Biophys. J. 2014, 107, 1885-1895. doi:10.1016/j.bpj.2014.09.007

33. McIntyre, J. C.; Sleight, R. G. Biochemistry 1991, 30, 11819-11827. doi:10.1021/bi00115a012

34. Chang, Q.-I.; Gummadi, S. N.; Menon, A. K. Biochemistry 2004, 43, 10710-10718. doi:10.1021/bi049063a

35. Bonner, W. A. J. Am. Chem. Soc. 1958, 80, 3372-3379. doi:10.1021/ja01546a045

36. Warren, C. D.; Liu, I. Y.; Herscoves, A.; Jeanloz, R. W. J. Biol. Chem. 1975, 250, 8069-8078.

37. Wu, Y.-W.; Alexandrov, K.; Brunsveld, L. Nat. Protoc. 2007, 2, 2704-2711. doi:10.1038/nprot.2007.401

38. Lee, B.; Sun, W.; Lee, H.; Basavarajappa, H.; Sulaiman, R. S.; Sishtla, K.; Fei, X.; Corson, T. W.; Seo, S.-Y. Bioorg. Med. Chem. Lett. 2016, 26, 4277-4281. doi:10.1016/j.bmcl.2016.07.043

39. Ren, T.; Zhang, G.; Liu, D. Tetrahedron Lett. 2001, 42, 1007-1010. doi:10.1016/s0040-4039(00)02221-8

40. Yu, B.; van Ingen, H.; Vivekanandan, S.; Rademacher, C.; Norris, S. E.; Freedberg, D. I. J. Magn. Reson. 2012, 215, 10-22. doi:10.1016/j.jmr.2011.09.037

41. Kotowycz, G.; Lemieux, R. U. Chem. Rev. 1973, 73, 669-698. doi:10.1021/cr60286a004

42. Bock, K.; Pedersen, C. J. Chem. Soc., Perkin Trans. 2 1974, 293-297. doi:10.1039/p29740000293

\section{License and Terms}

This is an Open Access article under the terms of the Creative Commons Attribution License (http://creativecommons.org/licenses/by/4.0). Please note that the reuse, redistribution and reproduction in particular requires that the authors and source are credited.

The license is subject to the Beilstein Journal of Organic Chemistry terms and conditions:

(https://www.beilstein-journals.org/bjoc)

The definitive version of this article is the electronic one which can be found at: doi:10.3762/bjoc. 16.145 